\title{
BIOGENIC SYNTHESIS OF SILVER NANOPARTICLES USING TRACHYSTEMON ORIENTALIS L. AND THEIR ANTIBACTERIAL ACTIVITIES
}

\author{
Hasan Ufuk CELEBIOGLU1*, Rizvan IMAMOGLU², Recep TAS ${ }^{1}$ \\ ${ }^{1}$ Department of Biotechnology, Faculty of Science, Bartin University, Bartin, Turkey \\ ${ }^{2}$ Department of Molecular Biology and Genetics, Faculty of Science, Bartin University, Bartin, Turkey
}

https://doi.org/10.37904/nanocon.2021.4361

\begin{abstract}
Nanotechnology is a scientific field for the characterization, production, and application of nanoscale particles of 1-100 nm size. Due to their large surface area and small size, nanoparticles have different properties compared to bulk materials such as mechanical, electrical, magnetic, and chemical properties. They can be synthesized by physical, chemical and biological methods. The biosynthesis of nanoparticles is the synthesis of nanoparticles using microorganisms or plants with biomedical applications. This synthesis approach stands out as a cost-effective, environmentally friendly, bio-compatible, safe, and green approach.

The present study aims to synthesize silver nanoparticles by green chemistry using Trachystemon orientalis L. extract and to investigate anti-bacterial and anti-fungal effects properties.

UV-Visible absorption, fourier-transform infrared spectroscopy, and scanning electron microscopy analyses confirmed the synthesis. The results showed that silver nanoparticles have inhibitory effect on both gramnegative (E. coli, Klebsiella pneumonia and Pseudomonas aeruginosa) and gram-positive (Staphylococcus aureus and Enterococcus faecalis) bacterial strains. Furthermore, they showed anti-fungal activities against Candida utilis and Candida albicans.

Silver nanoparticles can affect the cell walls of the microorganism, changing the structure of cell membranes and even causing cell death. They can also increase the permeability of cell membranes, generate reactive oxygen species, and interrupt the replication of deoxyribonucleic acid.

In conclusion, green synthesis of silver nanoparticles using Trachystemon orientalis L. extract can be an effective method for biomedical purposes.
\end{abstract}

Keywords: Antibacterial, antifungal, nanoparticle, silver, Trachystemon orientalis L.

\section{INTRODUCTION}

Nanotechnology is a scientific field for the characterization, production and application of nanoscale particles of $1-100 \mathrm{~nm}$ size. Technologically, it is a new and rapidly developing technology that aims to bring new physical, chemical and biological properties to matter at the atomic and molecular level [1-2]. Due to their large surface area and small size, nanoparticles have different properties compared to bulk materials such as mechanical, electrical, magnetic and chemical properties [1,3]. In recent years, studies on nano-sized materials have become important and raise awareness. Nano-sized structures are of interest for all applications of nanotechnology, where the shape and size of nanoparticles determine their characteristic properties [4]. The main reason why these nanoscale structures attract attention and attract attention is that the substances show functionality with their own characteristics different from their different volumetric dimensions and structures [5]. Due to the unique physical, chemical, optical and mechanical properties of nanoparticles, they have many applications in different fields, including coating and paint, food, textile, energy, automotive and agriculture, cosmetics, space field, MRI contrast, separation and purification of cell parts, cells and biological molecules, 
tissue engineering heterogeneous catalysis, antimicrobial additives, UV protection, LCD technology, medicine and genetics, biodetection of pathogens, detection of proteins, investigation of DNA structure [6-27]. Nanoparticles (Nps) can be synthesized by physical, chemical and biological methods. Although many traditional methods are used physically and chemically for the synthesis of Nps, these methods create expensive and toxic by-products at the same time. Moreover, it is difficult to control the surface chemistry, size and structure of nanoparticles synthesized by these methods [28]. The biosynthesis of nanoparticles is the synthesis of nanoparticles using microorganisms and plants with biomedical applications. This synthesis approach; stands out as a cost-effective, environmentally friendly, bio-compatible, safe and green approach [29]. These natural strains and plant extracts used in the synthesis of nanoparticles secrete some phytochemicals that act as both a reducing agent and a capping or stabilizing agent. Due to the special phytochemicals they produce, plant parts such as roots, stems, leaves, fruits and seeds were used to synthesize Ag nanoparticles. Using natural extracts of plant parts in nanoparticle synthesis is a very environmentally friendly and inexpensive process. Plants have become the most preferred natural resources for nanoparticle synthesis, as they lead the large-scale and stable production of nanoparticles of different shapes and sizes [30]. Thus, the aim of the present study is to synthesize silver nanoparticles from metal oxides by green chemistry using Trachystemon orientalis $\mathrm{L}$. and to investigate their anti-bacterial and antifungal effects.

\section{MATERIALS AND METHODS}

\subsection{Preparation of the plant extracts}

Trachystemon orientalis L. Bartin was obtained from the local public market. Trachystemon orientalis L. was extracted according to the method suggested by Rao et al [31]. The plant was washed 3 times with deionized water. The washed leaves were dried and passed through a food processor and divided into small pieces. 10 $\mathrm{g}$ of the obtained herbal powder was mixed into $100 \mathrm{~mL}$ of distilled water and extracted by standing in a water bath for one hour at room temperature. The resulting mixture was extracted by filtering through Whatman filter paper and was freshly prepared and used in the synthesis stage. Stored in a dark glass bottle at $+4{ }^{\circ} \mathrm{C}$ to be used as a stock.

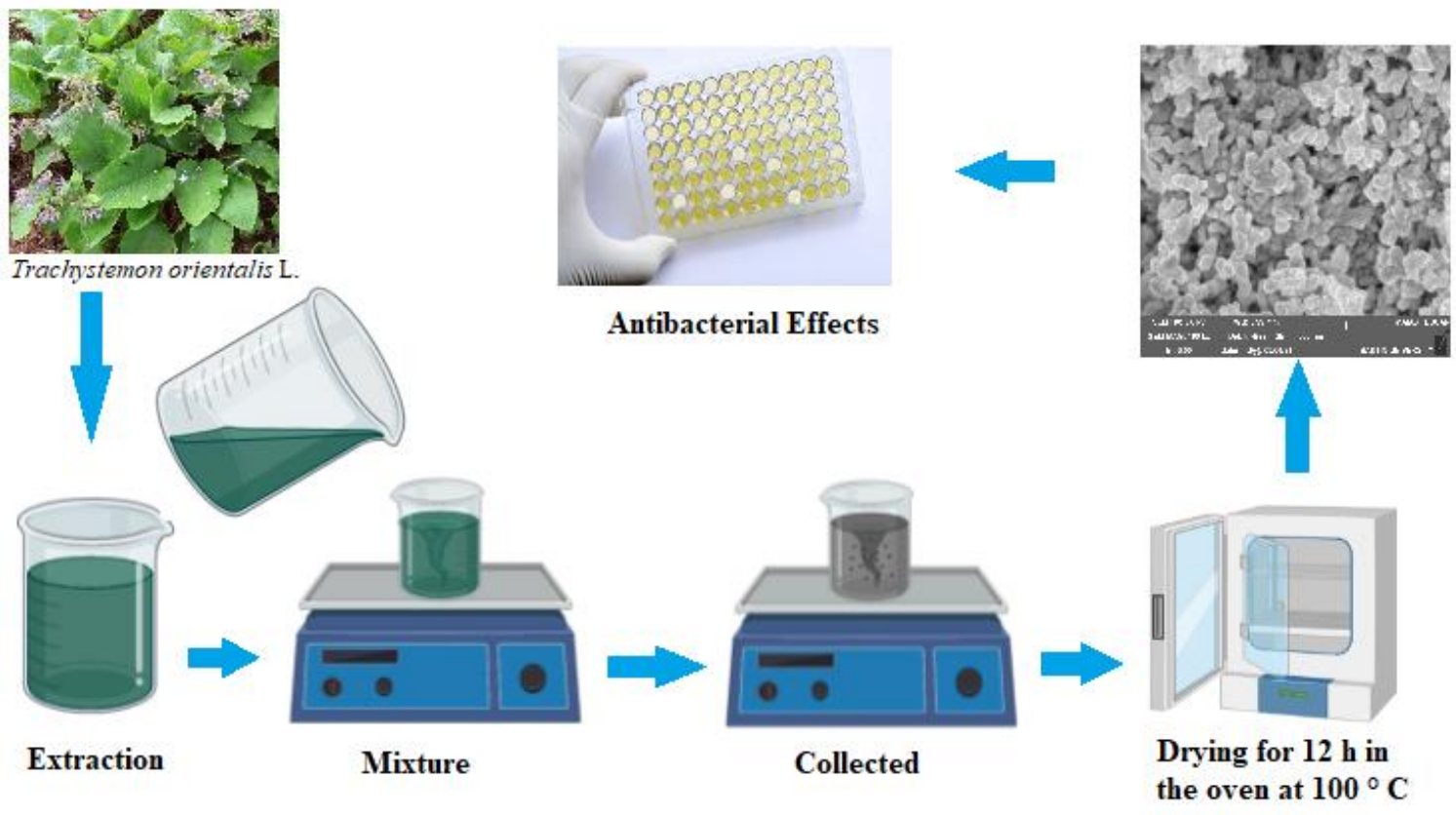

Figure 1 Schematic representation of AgNP synthesis 


\subsection{Synthesis of silver nanoparticles}

To $10 \mathrm{~mL}$ of $\mathrm{AgNO}_{3}$ solution at a concentration of $0.1 \mathrm{M}, 50 \mathrm{~mL}$ of Trachystemon orientalis $\mathrm{L}$. extract was added dropwise and stirred on magnetic stirrer at room temperature for $24 \mathrm{~h}$ at a constant stirring speed (500 rpm). The formation of AgNPs 15 min after the addition of the extract was observed by observing the color of the solution from green to blackish-gray (Figure 1). The resulting AgNPs were purified by centrifugation at $8,000 \mathrm{rpm}$ for 15 minutes. The nanoparticles separated from the suspension by centrifugation were washed twice with pure water and dried in a vacuum oven at $100^{\circ} \mathrm{C}$ for 12 hours. The nanoparticles obtained were stored in centrifuge tubes for use in antimicrobial studies.

\subsection{Characterization of $\mathrm{c}$ Ag nanoparticles}

The optical properties of AgNPs were characterized by taking UV-Vis region spectra (THERMO, Model Multiscaner spectrophotometer) between 200-800 nm. FTIR (Shimadzu Iraffinity-1) was used for functional group analysis. Particle morphology and size was measured by SEM (TESCAN, MAIA3 XM). The crystal structure and particle size of AgNPs was calculated using XRD analysis. XRD analysis was performed using a powder X-ray diffractometer (Rigaku, Smartlab).

\subsection{Anti-bacterial and Antifungal Effects of Silver Nanoparticle}

Broth Micro-dilution Assay was used in order to investigate antibacterial activities of the compounds (Brandt et al., 2010), with some modifications. Briefly, The antimicrobial activity of the synthesized TO-AgNPs was determined against gram-negative bacterial strains ( $K$. pneumonia, $P$. aeruginosa, and E.coli), gram-positive bacterial strains ( $E$. faecalis and $S$. aureus), and fungal strains (C. albicans and $C$. utilis) from frozen stocks for $24 \mathrm{~h}$ at $37^{\circ} \mathrm{C}$. Then, new cultures were prepared until $0.5 \mathrm{McF}$ arland Unit at $37^{\circ} \mathrm{C}$. In total $200 \mu \mathrm{L}$ of microtiter plate wells, $20 \mu \mathrm{L}$ of bacterial cultures were inoculated with NB containing different concentrations of the compounds suspended in DMSO (0-30 mM). Negative controls were prepared using LB without bacteria. Positive controls did not contain any compounds, but respective amount of DMSO. Absorbances of microtiter plates were read at $600 \mathrm{~nm}$ using a micro-plate reader before $\left(0^{\text {th }} \mathrm{h}\right)$ and after $\left(24^{\text {th }} \mathrm{h}\right)$ the incubation at $37^{\circ} \mathrm{C}$. Bacterial viability was measured as percentage of compound-treated bacterial groups to the positive control (bacterial viability of positive control was taken as $100 \%$ ). Minimum inhibitory concentrations (MIC) were calculated using the plot of nanoparticle concentration versus relative bacterial growth.

Statistical analysis and comparable data sets were evaluated using GraphPad Prism 8.0.2 software with a two-way ANOVA test. Probability values of $p<0.05$ were considered statistically significant.

\section{RESULTS AND DISCUSSION}

\subsection{UV-Visible absorption analysis}

The UV-Vis spectrum of TO-AgNPs obtained by using the extract of leaf parts of the plant Trachystemon orientalis $\mathrm{L}$. with the green synthesis method is shown in Figure 2. The wavelength of maximum absorption in the UV spectrum of TO-AgNPs was determined as $419 \mathrm{~nm}$.

\subsection{Fourier-transform infrared spectroscopy (FTIR)}

FTIR was performed to determine the nature of possible natural products responsible for the surface coating and efficient stabilization of AgNPs synthesized using the water extract of Trachystemon orientalis. FTIR spectrum of the sample is shown in Figure 3. The broad peak in the range of $3100-3400 \mathrm{~cm}^{-1}$ is caused by the $\mathrm{O}-\mathrm{H}$ stresses of the alcoholic and phenolic groups found in the polymeric structure of the plant and the $\mathrm{N}$ $\mathrm{H}$ stress of the amine groups. Peaks at 2920 and $2844 \mathrm{~cm}^{-1}$ belong to aliphatic $\mathrm{C}-\mathrm{H}$ stresses. 


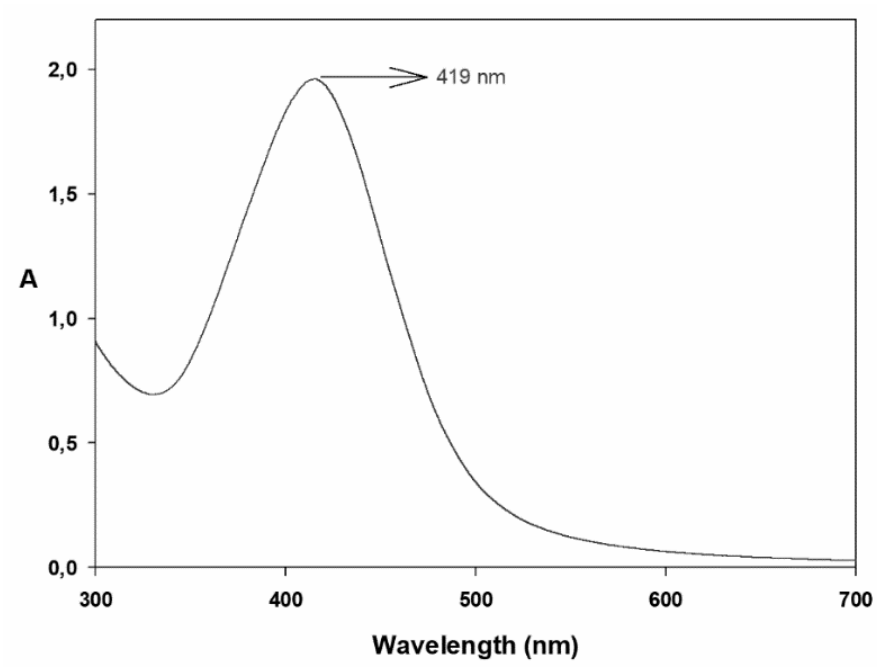

Figure 2 The UV-Vis spectrum of TO-AgNPs

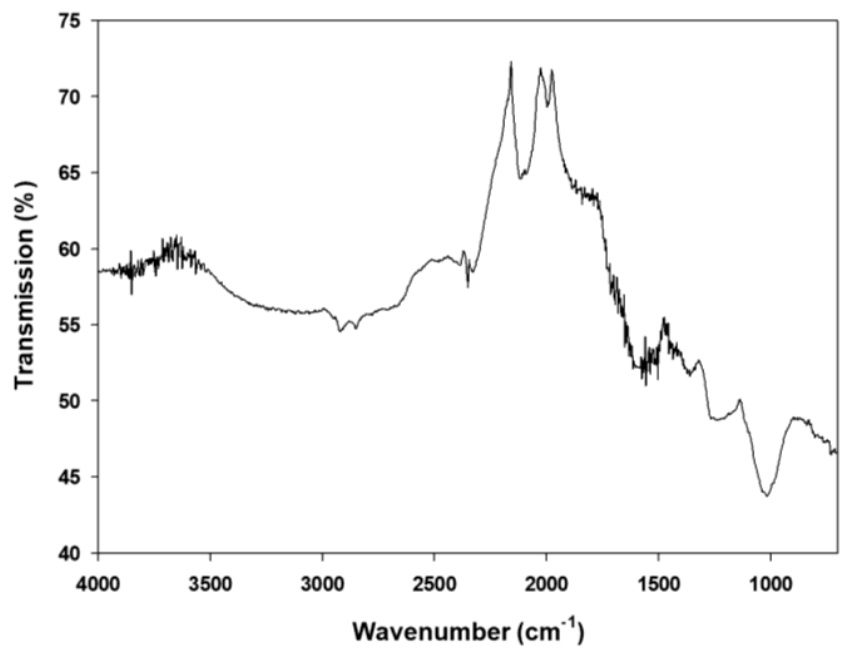

Figure 3 FTIR spectrum of TO-AgNPs

\subsection{XRD analysis}

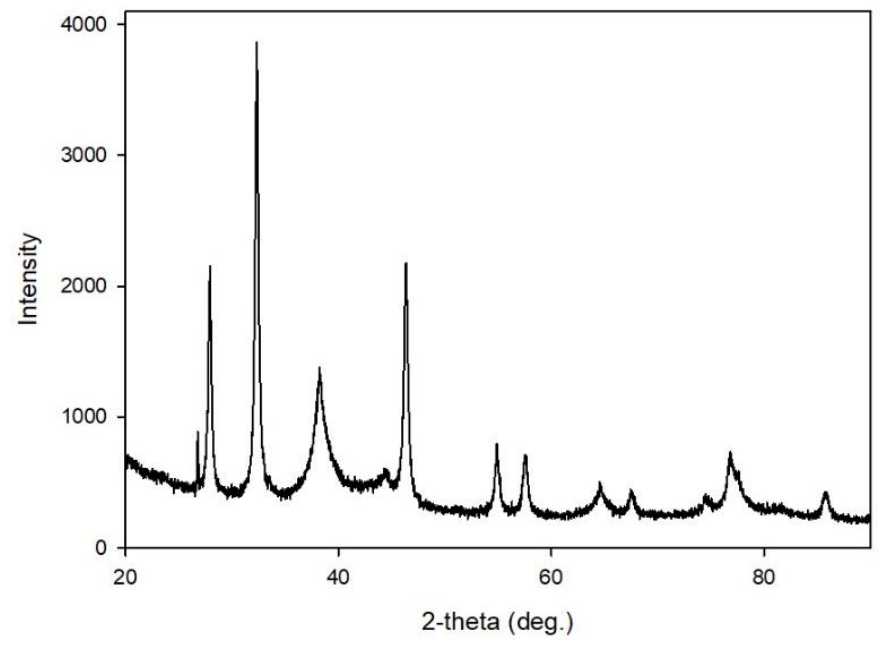

Figure 4 XRD of TO-AgNPs 


\subsection{Scanning electron microscopy (SEM) study of AgNPs}

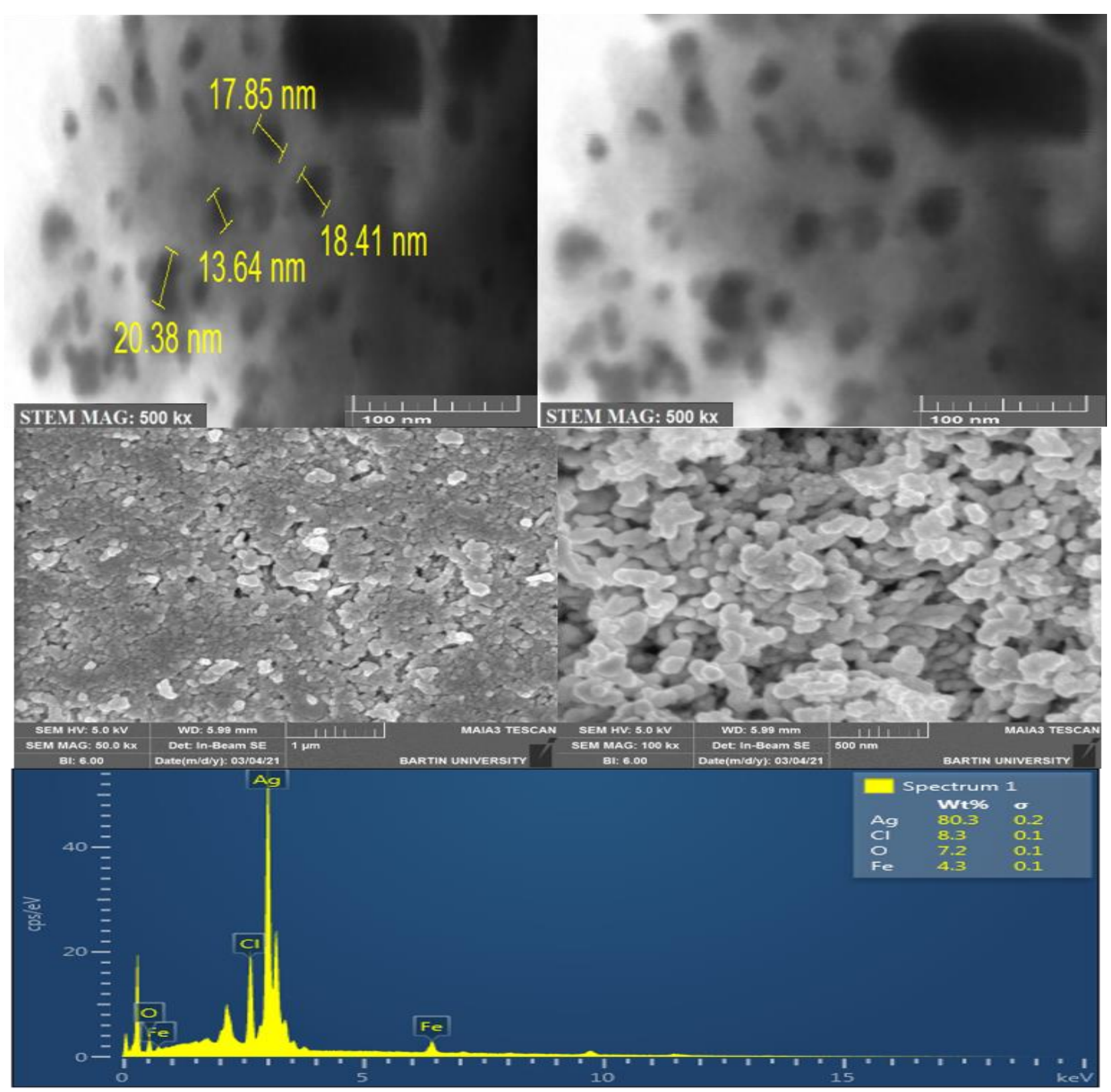

Figure 5 SEM results of TO-AgNPs

\subsection{Antibacterial activity}

In the present study, anti-bacterial effects of the nanoparticle were examined the. According to the experimental MIC data, the TO-AgNPs have shown a greater inhibitory effect on both gram-negative (E. coli, Klebsiella pneumonia and Pseudomonas aeruginosa) and gram-positive (Staphylococcus aureus and Enterococcus faecalis) bacterial strains TO-AgNPs $C$. utilis, and $C$. albicans fungi showed an inhibitory effect on it depending on the dose (Figure 6). 


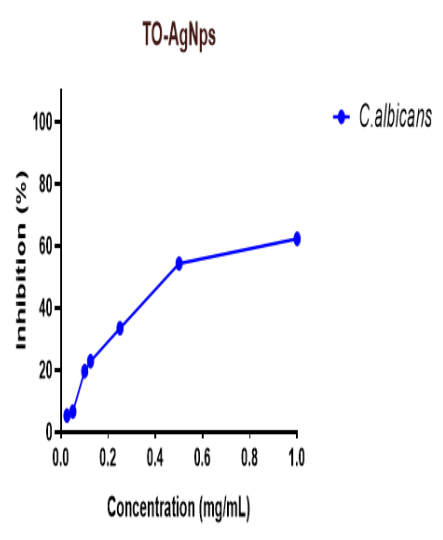

TO-AgNps

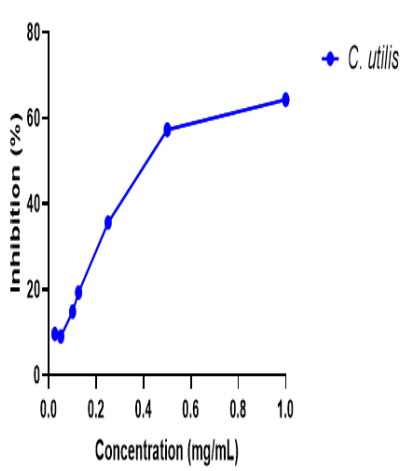

TO-AgNps

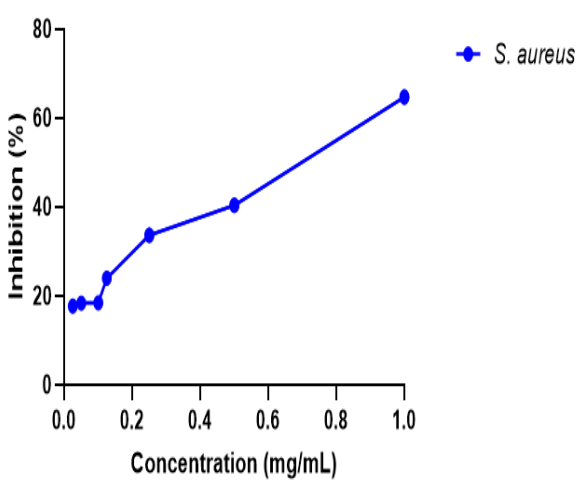

TO-AgNps

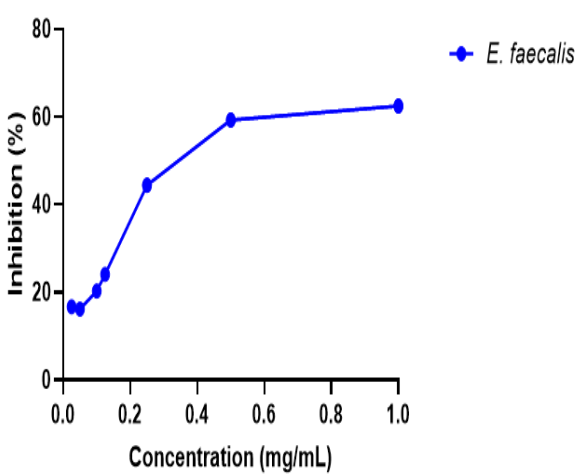

TO-AgNps

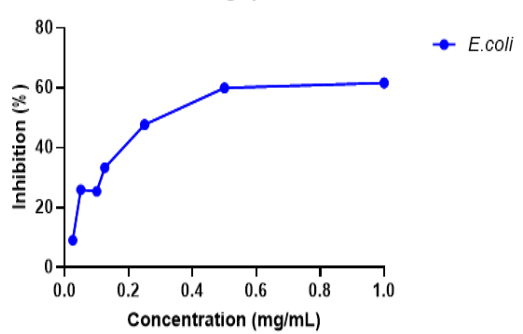

TO-AgNps

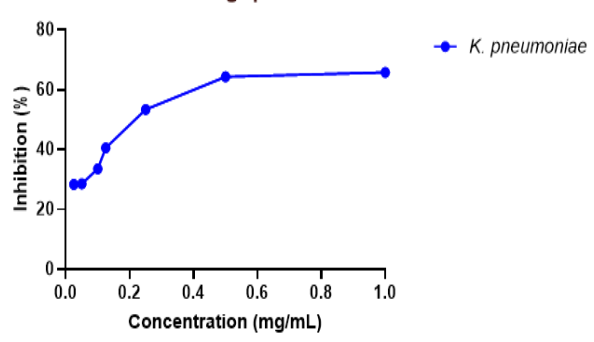

TO-AgNps

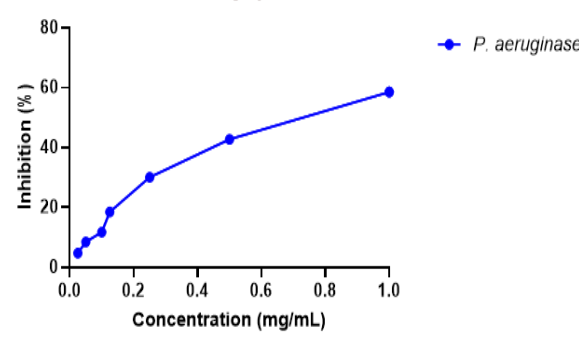

Figure 6 Growth inhibition graph of pathogenic microorganisms exposed to TO-AgNPs

Table 1 Minimum inhibitory concentrations of TO-AgNPs

\begin{tabular}{|l|l|}
\hline Microorganisms & $\begin{array}{l}\text { MIC Values of TO-AgNPs } \\
(\mathrm{mg} / \mathrm{mL})\end{array}$ \\
\hline S. aureus & $0.619 \pm 0,07$ \\
\hline P. aeruginosa & $0.676 \pm 0.04$ \\
\hline K. pneumoniae & $0.232 \pm 0.04$ \\
\hline E.coli & $0.352 \pm 0.06$ \\
\hline E. faecalis & $0.408 \pm 0.08$ \\
\hline C. albicans & $0.495 \pm 0.04$ \\
\hline C. utilis & $0.463 \pm 0.06$ \\
\hline
\end{tabular}

\section{CONCLUSION}

In this study, we reported the synthesis of silver nanoparticles from Trachystemon orientalis plant. We carried out antibacterial and antifungal studies of the synthesized nanoparticles. Synthesized TO-AgNPs showed significant antibacterial and antifungal properties depending on the dose. 


\section{ACKNOWLEDGEMENTS}

\section{The authors acknowledges Bartin University for supporting this study.}

\section{REFERENCES}

[1] SINGH, A., DAR, M. Y., JOSHI, B., SHARMA, B., SHRIVASTAVA, S., and SHUKLA, S. Phytofabrication of silver nanoparticles: novel drug to overcome hepatocellular ailments. Toxicology reports. 2018, vol. 5, pp. 333-342.

[2] RAMSDEN, J. Applied nanotechnology: the conversion of research results to products. William Andrew. 2018. ISBN: 9780128133439.

[3] LLOYD, J. R., BYRNE, J. M., and COKER, V. S. Biotechnological synthesis of functional nanomaterials. Current Opinion in Biotechnology. 2011, vol. 22, no. 4, pp. 509-515.

[4] MAO, B. H., TSAI, J. C., CHEN, C. W., YAN, S. J., and WANG, Y. J. Mechanisms of silver nanoparticle-induced toxicity and important role of autophagy. Nanotoxicology. 2016, vol. 10, no. 8, pp. 1021-1040.

[5] RAO, SAPRA, S., SARMA, D. D., C. N. R., MULLER, A., and CHEETHAM, A. K. The Chemistry of Nanomaterials: Synthesis, Properties and Applications. Chemistry of Nanomaterials. [online]. 2004, 9783527602476. Available from: https://doi.org/10.1002/352760247X

[6] ANYAOGU, K. C., FEDOROV, A. V., AND NECKERS, D. C., Synthesis, characterization, and antifouling potential of functionalized copper nanoparticles, Langmuir. 2008, vol. 24, no. 8, pp. 4340-4346.

[7] KUMAR, A., VEMULA, P. K., AJAYAN, P. M., AND JOHN, G. Silver-nanoparticle embedded antimicrobial paints based on vegetable oil. Nature Materials. 2008, vol. 7, no. 3, p. 236.

[8] ESPITIA, P. J. P., SOARES, N. D. F. F., DOS REIS COIMBRA, J. S., DE ANDRADE, N. J., CRUZ, R. S., and MEDEIROS, E. A. A. Zinc oxide nanoparticles: synthesis, antimicrobial activity and food packaging applications. Food and Bioprocess Technology. 2012, vol. 5, no. 5, pp. 1447-1464.

[9] WEIR, A., WESTERHOFF, P., FABRICIUS, L., HRISTOVSKI, K., and VON GOETZ, N., Titanium dioxide nanoparticles in food and personal care products. Environmental Science and Technology. 2012, vol. 46, no. 4, pp. 2242-2250.

[10] KATHIRVELU, S., D'SOUZA, L., AND DHURAI, B., UV protection finishing of textiles using ZnO nanoparticles. Indian Journal of Fibre and Textile Research. 2009, vol. 34, pp. 267-273.

[11] LI, Y., WU, Y., AND ONG, B. S. Facile synthesis of silver nanoparticles useful for fabrication of high-conductivity elements for printed electronics. Journal of the American Chemical Society. 2005, vol. 127, no. 10, pp. 3266-326.

[12] FREY, N. A., PENG, S., CHENG, K., AND SUN, S. Magnetic nanoparticles: synthesis, functionalization, and applications in bioimaging and magnetic energy storage. Chemical Society Reviews. 2009, vol. 38, no. 9, pp. 2532-2542.

[13] IM, K., CHO, K., KIM, J., and KIM, S. Transparent heaters based on solution processed indium tin oxide nanoparticles. Thin Solid Films. 2010, vol. 518, no. 14, pp. 3960-3963,

[14] MÜLLER, R. H., RADTKE, M., and WISSING, S. A. Solid lipid nanoparticles (SLN) and nanostructured lipid carriers (NLC) in cosmetic and dermatological preparations. Advanced Drug Delivery Reviews. 2002, vol. 54, pp. 131-155.

[15] VOEVODIN, N. N., KURDZIEL, J. W., and MANTZ, R., Corrosion protection for aerospace aluminum alloys by Modified Self-assembled Nanophase Particle (MSNAP) sol-gel. Surface and Coatings Technology. 2006, vol. 201, no. 3-4, pp. 1080-1084.

[16] MULDER, W. J., STRIJKERS, G. J., VAN TILBORG, G. A., GRIFFIOEN, A. W., and NICOLAY, K.. Lipid-based nanoparticles for contrast-enhanced MRI and molecular imaging. NMR in Biomedicine. An International Journal Devoted to the Development and Application of Magnetic Resonance In vivo. 2006, vol. 19, no. 1, pp. 142-164.

[17] CHIANG, C. L., SUNG, C. S., WU, T. F., CHEN, C. Y., and HSU, C. Y. Application of superparamagnetic nanoparticles in purification of plasmid DNA from bacterial cells. Journal of Chromatography B. 2005, vol. 822, no. 1-2, pp. 54-60.

[18] LEE, I. S., LEE, N., PARK, J., KIM, B. H., YI, Y. W., KIM, T., and HYEON, T. Ni/NiO core/shell nanoparticles for selective binding and magnetic separation of histidine-tagged proteins. Journal of the American Chemical Society. 2006, vol. 128, no. 33, pp. 10658-10659. 
[19] GOLDBERG, M., LANGER, R., and JIA, X. Nanostructured materials for applications in drug delivery and tissue engineering. Journal of Biomaterials Science Polymer Edition. 2007, vol. 18, no. 3, pp. 241-268.

[20] YU, C. H., TAM, K., and TSANG, E. S. Chemical methods for preparation of nanoparticles in solution. Handbook of Metal Physics. 2008, vol. 5, pp. 113-141.

[21] FONDEVILA, M., HERRER, R., CASALLAS, M. C., ABECIA, L., and DUCHA, J. J. Silver nanoparticles as a potential antimicrobial additive for weaned pigs. Animal Feed Science and Technology. 2009, vol. 150, no. 3-4, pp. 259-269.

[22] SHI, L., SHAN, J., JU, Y., AIKENS, P., and PRUD'HOMME, R. K. Nanoparticles as delivery vehicles for sunscreen agents. Colloids and Surfaces A: Physicochemical and Engineering Aspects. 2012, vol. 396, pp. 122129.

[23] SHIRAISHI, Y., TOSHIMA, N., MAEDA, K., YOSHIKAWA, H., XU, J., and KOBAYASHI, S. Frequency modulation response of a liquid-crystal electro-optic device doped with nanoparticles. Applied Physics Letters. 2002, vol. 81, no. 15 , pp. 2845-2847.

[24] CHO, K., WANG, X. U., NIE, S., and SHIN, D. M., Therapeutic nanoparticles for drug delivery in cancer. Clinical Cancer Research. 2008, vol. 14, no. 5, pp. 1310-1316.

[25] SANVICENS, N., PASTELLS, C., PASCUAL, N., and MARCO, M. P. Nanoparticle-based biosensors for detection of pathogenic bacteria. TrAC Trends in Analytical Chemistry. 2009, vol. 28, no. 11, pp. 1243-1252.

[26] YOU, C. C., MIRANDA, O. R., GIDER, B., GHOSH, P. S., KIM, I. B., ERDOGAN, B., SAI A. K., BUNZ U. H. F. and ROTELLO, V. M. Detection and identification of proteins using nanoparticle-fluorescent polymer 'chemical nose'sensors. Nature Nanotechnology. 2007, vol. 2, no. 5, p. 318.

[27] WANG, L., LIU, X., HU, X., SONG, S., and FAN, C. Unmodified gold nanoparticles as a colorimetric probe for potassium DNA aptamers. Chemical Communications. 2006, vol. 36, pp. 3780-3782.

[28] K. GUDIKANDULA, S.C. MARINGANTI. Synthesis of silver nanoparticles by chemical and biological methods and their antimicrobial properties. J Exp Nanosci. 2016, vol. 11, pp. 714-721.

[29] ABDUL, H., SIVARAJ, R. and VENCKATESH, R. Green Synthesis and Characterization of Zinc Oxide Nanoparticles from Ocimum Basilicum L. Var. Purpurascens Benth.-Lamiaceae Leaf Extract. Mater Lett. 2014, vol. 131, pp. 16-18.

[30] QU, J., YUAN, X., WANG, X., and SHAO, P. Zinc Accumulation and Synthesis of Zno Nanoparticles Using Physalis alkekengi L. Environ Pollut, 2011, no. 159, pp. 1783-1788.

[31] RAO, KG, ASHOK, CH, RAO, KV, CHAKRA, CHS, AKSHAYKRANTH, A. Eco-friendly synthesis of MgO nanoparticles from orange fruit waste. Int J Appl Phys Sci. 2015, vol. 2, no. 3, pp. 1-6. 